\title{
IMPROVING COGNITIVE LEARNING OUTCOMES BY USING E-MODULES
}

\author{
Dyah Aniza Kismiati \\ Alumni Prodi Pendidikan Biologi Program Pacasarjana Universitas Negeri Yogyakarta \\ Jl. Colombo No 1, Yogyakarta \\ Email: anizady93@gmail.com
}

\begin{abstract}
:
This study aims to determine the effect of the use of e-modules in improving student cognitive learning outcomes. This type of research is a Research and Development study with ADDIE model with a nonequivalent pretest-posttest control group design. This product was validated by experts and was also limited to 21 class XI students. The research sample is 2 classes based on purposivesampling technique, class X MIPA 5 as a control class and class X MIPA 1 as an experimental class. The instrument used: a matter of cognitive learning outcomes. Data were analyzed through Independent Sample T-Test and Normalized Gain Score (N-Gain Score). The results showed that the developed E-module had a significant effect on students' cognitive learning outcomes as evidenced by the significance value of $0,000<\alpha 0.05$ and the category of height increase from the N-Gain Score calculation of 0.846 .
\end{abstract}

\begin{abstract}
Abstrak:
Penelitian ini bertujuan untuk mengetahui pengaruh penggunaan e-modul dalam meningkatkan hasil belajar kognitif siswa. Jenis penelitian ini merupakan penelitian Research and Development dengan model ADDIE dengan desain nonequivalent pretest-posttest control group. Produk ini divalidasi oleh para ahli dan juga diujicobakan secara terbatas pada 21 siswa kelas XI. Sampel penelitian yaitu 2 kelas berdasarkan teknik purposive sampling, kelas X MIPA 5 sebagai kelas kontrol dan kelas X MIPA 1 sebagai kelas eksperimen. Instrumen yang digunakan adalah soal hasil belajar kognitif. Data dianalisis melalui Independent Sample T-Test dan Normalized Gain Score ( $N$-Gain Score). Hasil penelitian menunjukkan bahwa E-modul yang dikembangkan berpengaruh secara signifikan terhadap hasil belajar kognitif siswa yang dibuktikan dengan nilai signifikansi $0.000<\alpha 0.05$ dan kategori peningkatan tinggi dari hasil penghitungan $N$-Gain Score sebesar 0.846 .
\end{abstract}

Keywords:

E-modules, Cognitive Learning Outcomes, Improve, Effect

How to Cite: Kismiati, D. A. (2020). Improving Cognitive Learning Outcomes by Using E-Moduls. Lentera Pendidikan : Jurnal Ilmu Tarbiyah dan Keguruan, 23(1), 44-52. https://doi.org/10.24252/lp.2020v23n1i5.

\section{INTRODUCTION}

The globalization era offers various facilities in accessing human needs, including communication. Information and communication flow very quickly as a positive impact on the progress of Science and Technology. This also contributes to the world of education. One of them is the emergence of new technologies in learning, namely mobile learning. It is in line with Darmawan's (2016: 1) point of view that by following the highly rapid 
globalization and development era signed by the product growth and technology utilization, the learning concept is shifted into an effort to embody the modern learning. Crompton, Burke, \& Gregori (2017: 2) defined mobile learning as learning across a multiple context in the form of content interaction by using personal electronical devices. Clark Quinn (2000: 1) defines the concept of mobile learning or also called e-learning as follows:

"The intersection of mobile computing and e-learning: accessible resources wherever you are, strong search capabilities, rich interaction, powerful support for effective learning, and performance-based assessment. Mobile learning independent of location in time or space" (Quinn, 2000: 1).

In line with with the definition, Laurensius (2017: 1) stated that e-learning can become as tool aid in a reflectional learning process because the students are able to do self-learning from unlimited places by using internet connection. Therefore, mobile learning is a teaching resource that can be accessed anywhere, with strong capabilities to support the creation of effective learning, wherever and whenever we are. According to Boruf dan Storie in Ponce, Pereira, Carvalho, Mendez, \& Nalvo (2017: 613), the main benefit of mobile learning utilization are the ease of getting effective information when needed, accessibility, and mobile utility due to its compact size, portability, fast information access, time usage, and efficient flexibility. According to Kukulska-Hulme \& Traxler (2005: 1), there are two basic factors that related e-learning technology, namely cellular devices and cellular operating systems. The examples of mobile devices like cellphones which are also referred to as smart phones (smartphones), laptops, and handheld computers (Personal Digital Assistants or PDAs) or tablet PCs.

Mobile learning has many benefits that support learning experiences. The results of Issac's research (2014: 1) revealed that the use of mobile learning makes it easy for anyone to access learning material whenever and wherever they are. Therefore, mobile learning has the concept of distance learning (without having to face-to-face in the room). The results of this study become as a reference for further study of mobile learning and its benefits. Mobile learning as a learning resource can be presented in several forms, such as electronic modules (e-modules), interactive learning videos, and others.

E-modules are digital modules that are able to help the students in understanding a concept. E-modules provide their own attraction supporting the students' willingness to know the contents (Susilawati, Pramusinta, \& Saptaningrum, 2020: 38). E-modules have the same characteristics as printed modules, which need to contain five things, like: self instructional, self contained, adaptive, stand alone dan user friendly (Daryanto, 2013: 911). The e-modules used in structured and independent learning can stimulate students to explore learning material. It allows students to absorb learning materials independently. In line with this, the learning objectives that teachers expect can be achieved through the use of e-modules will be exceeded, namely improving learning outcomes. Learning outcomes are the ability of students possessed after getting a learning experience. Learning outcomes are not only about knowledge, but also attitudes and behaviors. This is 
based on the opinion that learning outcomes are patterns of action, values, knowledge, attitudes, rewards, abilities, and skills (Hamalik, 2004: 31) as well as changes that occur in students and also that involve in cognitive, affective, and psychomotoic aspects as learning outcomes (Susanto, 2013: 5). Learning outcomes can be viewed on two sides, namely from the students' side, learning outcomes are the better levels of mental development if compared to pre-learning, from the teacher's side, learning outcomes are the completions of the instructional materials. (Mustika, Saptanigrum, \& Susilawati, 2016: 64).

Bloom in Purnomo, Sukarjo, \& Abidin (2020: 106) classifies learning outcomes into 3 domains, namely: (1) cognitive domains, (2) affective domains, and (3) psychomotoric domains. According to Suprijono in Mustika, Saptaningrum, \& Susilawati (2016: 64), cognitive domains cover knowledge, comprehension, application, analysis, synthesis, and evaluation. Learning outcomes from the cognitive domain are oriented towards thinking abilities, including simple abilities to the ability to solve problems. Measurement of cognitive learning outcomes by Krathwohl (2010: 43) include: remembering (C1), understanding (C2), applying (C3), analyzing (C4), evaluating (C5), and making (C6)(Anderson \& Krathwohl, 2010: 43). Anderson \& Krathwohl (2010: 43) also explain that learning outcomes of affective domains related to attitudes, such as acceptance, satisfaction in response, judgment, organization, and value complexes, while the psychomotoric domains, according to Simpson Subali (2012: 36) consist of perception, readiness to play an active role, guided responses, mechanisms, complex, adaptive, and original open responses.

E-modules can be a great solution for transferring independent learning materials to students. It is because e-modules have some more advantages than printed modules generally used. Putri, Sugihartini, Wirawan, \& Sunarya (2016: 217) state some advantages of e-modules in their research that they are more interactive, easy in navigation, enable display/ picture, audio, video and animation, as well as equipped with tests/ formative quizzes that allow immediate automatic feedback. Thus, students can enrich their learning experience by using e-modules. This principle is in line with the learning objectives of the enrichment program, which aims to strengthen aspects of competency that have been achieved by students (Subali, 2016: 168). The materials presented are the enrichment of classical learning materials that have been structured in the education curriculum in Indonesia. One example of enrichment materials on the biology is the isolation and characterization of bacteria. Isolation and Characterization Bacterial materials packaged in e-modules will attract students to learn them, so it is expected to improve students' cognitive learning outcomes.

\section{RESEARCH METHOD}

This study uses a quasi-experimental method with the Nonequivalent Control Group Pretest Posttest Design as shown in table 1. 
Tabel 1. Nonequivalent Control Group Pretest Posttest Design

\begin{tabular}{cccc}
\hline & Pretest & Treathment & Postest \\
\hline $\mathrm{O}_{1}$ & - & $\mathrm{O}_{2}$ \\
\hline $\mathrm{O}_{3}$ & $\mathrm{X}_{1}$ & $\mathrm{O}_{4}$ \\
\hline
\end{tabular}

Informations:

$01=$ pretest control group

02 = posttest control group

03 = experimental pretest group

$04=$ posttest experimental group

$\mathrm{X} 1$ = use of e-modules

(Source: Subali, 2016)

The sample used in this study was obtained based on a purposive sampling technique consisting of two groups, one group as a control group (without using e-modules but through peer tutoring in answering questions in problems) and another group as an experimental group (using e-modules). Both of groups are students of class X MIPA in SMA $\mathrm{N} 1$ Jetis Bantul. In the control group, the samples were 29 students while the samples of students used as the experimental group were 28 students with the same initial ability level. Both of groups were given the same test instrument that measured improvement in cognitive learning outcomes. The test instrument consisted of 10 multiple choice questions and 2 essay items.

Pretest and posttest data obtained in control and experimental groups were analyzed using the SPSS 16.0 program using paired sample $t$ tests to find out the increase in cognitive learning outcomes before learning (pretest) with after learning (posttest) in each group (control and xperimental groups) . In addition, the data were analyzed with an $\mathrm{N}$-Gain score to find out the level of improvement in students' cognitive learning outcomes between the control group and the experimental group.

The N-Gain score is obtained through the formula below:

$$
\mathrm{g}=\frac{\text { posttest score }- \text { pretest score }}{\text { maximum score }- \text { pretest score }}
$$

Table 2 shows the normalized gain high-low scores ( $\mathrm{N}-\mathrm{Gain}$ ) which is categorized by Agustin, Haryanto, \& Efwinda (2020: 58) as follows:

Table 2. Conversion of N-Gain Score to Cognitive Learning Outcomes Level

\begin{tabular}{cc}
\hline Score & Level \\
\hline $\mathrm{g}>0,7$ & High \\
$0,7>\mathrm{g}>0,3$ & Medium \\
$0,3>\mathrm{g}$ & Low \\
\hline
\end{tabular}




\section{RESULTS AND DISCUSSION}

This quasi-experimental research aims to determine the effect of the use of emodules on the learning outcomes of high school students. The research subjects are high school students in class X in SMA Negeri 1 Jetis Bantul. The developed e-module is the enrichment e-module for Bacteria Isolation and Characterization material. The use of emodules is used as an enrichment program for students who have exceeded the KKM scores in classical learning in the classroom. Before and after the use of this e-module, tests were carried out to determine whether there was an effect on improving student cognitive learning outcomes, both in the control class (without the use of e-modules) or in the experimental class that uses e-modules. The results of this study were analyzed using the Independent Sample T-Test analysis technique through the SPSS 16.0 program. Table 3 shows the results of the analysis of the effect of using e-modules.

Table 3. Results of Independent Sample T-Test Analysis for Cognitive Learning Outcomes Data

\begin{tabular}{|c|c|c|c|c|}
\hline & & \multicolumn{3}{|c|}{ T-test for Equality of Means } \\
\hline & & $T$ & df & $\begin{array}{l}\text { Sig (2 } \\
\text { tailed) }\end{array}$ \\
\hline Score & $\begin{array}{l}\text { Equal variances assumed } \\
\text { Equal variances not assumed }\end{array}$ & $\begin{array}{l}-7.522 \\
-7.487\end{array}$ & $\begin{array}{c}52 \\
47.618\end{array}$ & 0,000 \\
\hline
\end{tabular}

Based on table 3, it can be seen that the P-value or the significance of the t-test results is 0,000 . Thus, the significance value is $0,000<0.05$, so it can be concluded that if there is a real difference between cognitive learning outcomes of students at post-test with cognitive learning outcomes of students at pretest. In addition, the effect of increasing students' cognitive learning outcomes is also assessed from the calculation of the N-gain score shown in Tables 4 and 5 below.

Table 4. N-Gain Scores Increase in Student Learning Outcomes in the Control Group

\begin{tabular}{ccc}
\hline Score & Pretest & Posttest \\
\hline Minimum score & 6 & 38 \\
Maximum score & 52 & 83 \\
Average Score & 33,38 & 61,69 \\
\hline AverageGain Score & \multicolumn{3}{c}{$\mathbf{0 , 4 1 2}$} \\
Gain Score's Category & \multicolumn{2}{c}{ Moderate } \\
\hline
\end{tabular}

Table 5. N-Gain Scores Increase in Student Learning Outcomes in the Experimental Group

\begin{tabular}{lcc}
\hline \multicolumn{1}{c}{ Score } & Pretest & Posttest \\
\hline Minimum score & 18 & 52 \\
Maxmum score & 68 & 100 \\
Average Score & 33,71 & \\
\hline AverageGain Score & \multicolumn{2}{c}{$\mathbf{0 , 7 4}$} \\
Gain Score's Category & \multicolumn{2}{c}{ High } \\
\hline
\end{tabular}


The improvement of students' cognitive learning outcomes are known from the pretest and posttest scores by using test items in the form of 10 multiple choice items and 2 essay items. According of Tables 4 and 5, it can be seen that the average initial ability of students in both groups (control and experiment) are almost the same, 33.38 and 33.71. After learning, in the enrichment program, the average cognitive learning achievement between students in the control group and the experimental group are different, where the cognitive learning outcomes of students in the experimental group are higher than students in the control group as evidenced by the posttest score. In the control group, the posttest score was 61.69 while in the experimental group it was 82.89 . To be clearer about these differences, the data is presented in graphical form as in figure 1 below:

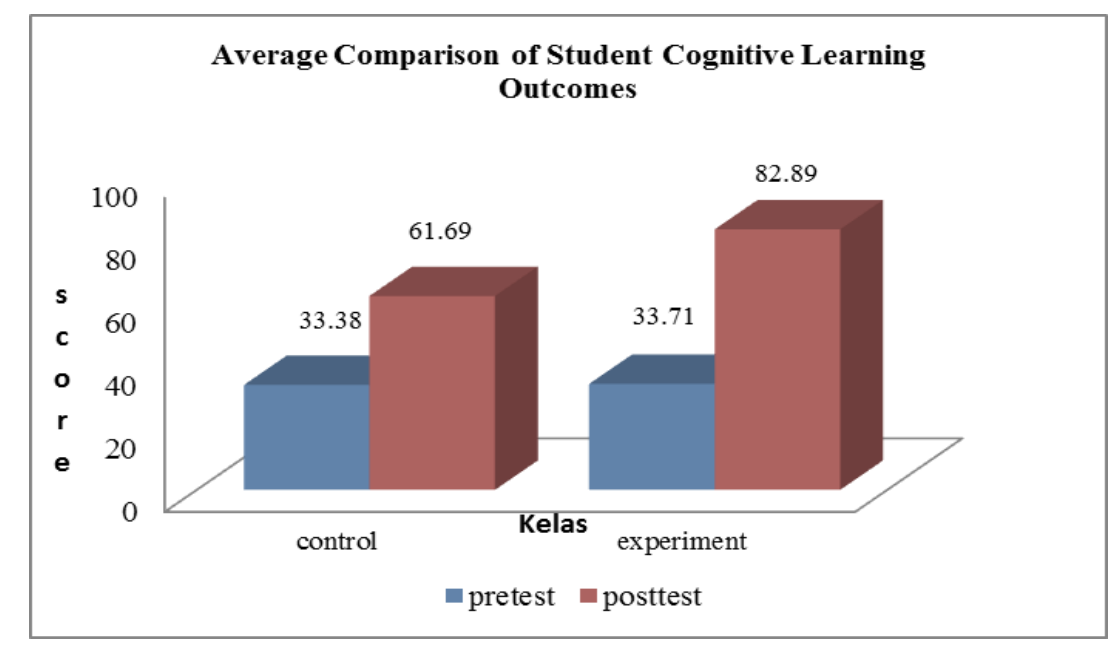

Figure 1. Pretest and Posttest Average Score Graph of Experiment and Control Classes

The difference in learning outcomes can be seen from the Average N-Gain Score. In Tables 5 and 6, it can be seen that students in the experimental group, who use e-modules, have the effect of increasing learning outcomes that are categorized high with an N-Gain value of 0.74 . Unlike the case with students in the control group whose improvement was moderate with an $\mathrm{N}$-gain value of only 0.41 . Thus, the use of e-modules has a significant impact on improving student cognitive learning outcomes.

The improvement of students' cognitive learning outcomes is caused by several things. Some of them are caused by the attractive appearance of e-modules. E-modules have lots of pictures, videos and also photos so the students are more interested and understand the learning materials faster. This is in accordance with the opinion of Purnomo, Indrowati, \& Karyanto (2013: 9-10) who said that if the pictures and videos in the module can stimulate students' interest in learning the module, an interested attitude is a good state for students in learning the contents of the modules. The improvement of the students' learning outcoms through the use of e-modules is also shown by Rhohman \& Suyanto (2018: 177) in a research that stated that e-modules were able to improve the students' cognitive learning outcomes with $\mathrm{N}$-Gain Score 0.62 which was categorized as medium. 
In addition to containing these components, e-modules isolation and bacterial characterization also uses communicative language so that students easily understand the material contained in e-modules. According to Widyaningrum (2013) modules created using communicative language and accompanied by examples (pictures) make it easy for students to understand. The pictures contained in the module clarify the content of the material, thereby producing attraction and reducing boredom for students.

The improvement of cognitive learning outcomes through the use of e-modules is also in accordance with the research findings conducted by IRIS Research Centers in the United States and Europe (2014: 2). It is explained that the use of online modules in learning could improve students' knowledge, application skills, and confidence. The students' learning outcomes by using online or electronic modules were significantly higher in applying conceptual measures of knowledge than students who participated in regular learning (The Iris Center, 2014: 2).

This improvement also becomes the evidence that the use of learning materials or teaching media is appropriate. Appropriate learning materials, according to Reiser, Robert, \& Dick (1996: 70-73) will be able to convey messages and information about learning goals and materials to students, motivate, help remember the prerequisites of knowledge, and present information together with examples that can facilitate students in understanding the material being taught. Furthermore, Reiser, Robert, \& Dick (1996: 71) explain that if the target of learning outcomes is the cognitive domain, the most important thing to do is present information (learning material) in a dense and meaningful way. Presentation of this information will be easier and more meaningful if conveyed through computer aided computers.

According to Pujiriyanto (2002: 10-11) the use of computer is oriented to facilitate the learning process through the transformation of information with various mental processes. Information sent through computer-aided computer programs and media will be stored primarily as long-term memory. Learning materials such as computer-assisted programs and media present learning material in the form of verbal, visual and audio that can stimulate the brain to produce more complex multisensory so as to be able to coordinate learning needs in the human cognitive system.

The success in using this e-module cannot be separated from several supporting factors, such as electronic devices that support the e-module application program, ease of operating electronic modules, teacher and student skills in running applications as well as clear guidance given by the teacher to students.

\section{CONCLUSION}

Based on the aims and the research findings, it can be concluded that the use of emodules has an effect on improving the students' cognitive learning outcomes categorized as high with an $\mathrm{N}$-gain value of 0.74 . The advice that researchers can provide is that it needs to be further investigated about the impact of using e-modules for other dimensions, such as the affective and social dimensions of the students. 


\section{REFERENCES}

Agustin, Lady, Haryanto, Z., \& Efwinda, S. (2020). Pengaruh Model Pembelajaran Inkuiri Terbimbing terhadap Kemampuan Berpikir Kritis Siswa Kelas XI SMA Negeri 9 Samarinda. Jurnal Literasi Pendidikan Fisika, 1(1), 56-64. file://C:/Users/PC/Downloads/Documents/80-Article Text-408-2-1020200302.pdf.

Anderson, L. ., \& Krathwohl, D. . (2010). Kerangka Landasan Untuk Pembelajaran, Pengajaran dan Asesmen (Revisi Taksonomi Pendidikan Bloom). Pustaka Pelajar.

Crompton, H., Burke, D., \& Gregori, K. H. (2017). The Use of Mobile Learning in PK-12 Education: A Systematic Review. Computers \& Education, 110, 51-63. https://doi.org/10.1016/j.compedu.2017.03.013.

Darmawan, D. (2016). Mobile Learning: Sebuah Aplikasi Teknologi Pembelajaran. Jakarta: Rajawali Pres.

Daryanto. (2013). Menyusun Modul. Yogyakarta: Gava Media.

Hamalik, O. (2004). Proses Belajar Mengajar. Jakarta: Bumi Aksara.

Jacob, S. M., \& Issac, B. (2008). The Mobile Devices and Its Mobile Learning Usage Analysis. Proceedings of the International MultiConference of Engineers and Computer $\begin{array}{llll}\text { Scientists (IMECS), } & \text { Hongkong, } & 1, & 19-21 .\end{array}$ https://arxiv.org/ftp/arxiv/papers/1410/1410.4375.pdf.

Kukulska-Hulme, A, \& Traxler, J. (2005). Mobile Learning: A Handbook for Educators and Trainers. Tailor \& Francis.

Laurensius, A. (2017). Platform E-Learning untuk Pembelajaran Pemrograman Web Menggunakan Konsep Progressive Web Apps. Institut Teknologi Sepuluh Nopember.

Mustika, Saptanigrum, E., \& Susilawati. (2016). Pengaruh Penggunaan LKS dengan Pendekatan Saintifik Pada Materi Objek IPA Kelas VII MTs Negeri 1 Semarang. Jurnal Penelitian Pembelajaran Fisika, 7(1), 63-71. https://doi.org/10.26877/jp2f.v7i1.1154.

Ponce, L. B., Pereira, A., Carvalho, L., Mendez, J. A. J., \& Nalvo, F. J. G. P. (2017). Learning With Mobile Technologies - Students' Behavior. Computers in Human Behavior, 72, 612-620. https://doi.org/10.1016/j.chb.2016.05.027.

Pujiriyanto. (2002). Teknologi untuk Mengembangkan Media dan Pembelajaran. Yogyakarta: UNY Press.

Purnomo, D., Indrowati, M., \& Karyanto, P. (2013). Pengaruh Penggunaan Modul Hasil Penelitian Pencemaran di Sungai Pepe Surakarta sebagai Sumber Belajar Biologi Pokok Bahasan Pencemaran Lingkungan terhadap Hasil Belajar Siswa. Journal of Jurnal Pendidikan Biologi, https://jurnal.fkip.uns.ac.id/index.php/bio/article/view/1439.27/0.

Purnomo, Sukarjo, \& Abidin, A. Z. (2020). Penerapan Model Pembelajaran Tanggung Jawab Pribadi dan Sosial Berbasis Lesson Study untuk Menguatkan Karakter Konservasi dan Meningkatkan Hasil Belajar. Jurnal Kreatif: Jurnal Kependidikan Dasar, 10(2), 100-116. https://journal.unnes.ac.id/nju/index.php/kreatif/article/view/23603.

Putri, N., Wirawan, I. M. A., \& Sunarya, I. M. G. (2016). Pengembangan E-Modul Mata Pelajaran Komposisi Foto Digital (Paket Keahlian Multimedia) dengan Model Pembelajaran Task Based Learning Pada Kelas XI di SMK 3 Mataram. Kumpulan Artikel Mahasiswa Pendidikan Teknik Informatika (KARMAPATI), 5(3), 215-222. 
https://doi.org/10.23887/karmapati.v5i3.8598.

Quinn, P. (2000). What In The World is The World Wide Web. Learning Media Limited.

Reiser, Robert, A., \& Dick, W. (1996). Instructional Planing: A Guide for Teachers. Allyn and Bacon.

Rhohman, M. F. F., \& Suyanto, S. (2018). Pengembangan E-Modul Pengayaan Keanekaragaman Jenis Tanaman Pangan Umbi Berbasis Kearifan Lokal di Kabupaten Gunungkidul Untuk Meningkatkan Kemandirian dan Hasil Belajar Kognitif Siswa Kelas X SMA. Jurnal Pend. Biologi-S1, 7(3), 168-178. file:///C:/Users/PC/Downloads/Documents/13712-30160-1-SM.pdf.

Subali, B. (2012). Prinsip Asesmen dan Evaluasi Pembelajaran. Yogyakarta: UNY Press.

Subali, B. (2016). Prinsip Asesmen dan Evaluasi Pembelajaran Edisi Kedua. Yogyakarta: UNY Press.

Susanto, A. (2013). Teori Belajar dan Pembelajaran di Sekolah Dasar. Jakarta: Kencana Prenada Media Group.

Susilawati, Pramusinta, \& Saptaningrum, E. (2020). Penguasaan Konsep Siswa Melalui Sumber Belajar e-Modul Gerak Lurus dengan Software Flipbook Maker. Unnes Physics Education Journal, 9(1), 36-43. https://doi.org/10.15294/upej.v9i1.38279.

The Iris Center. (2014). Online Learning and Teacher Education: Knowledge Acquisition, Application Skills, and Reported Confidence. Claremont Graduate University. https://iris.peabody.vanderbilt.edu/wp-content/uploads/2014/08/learner_out comes_IARLD_2014.pdf. 